\title{
Organized transnational crime in the Black Sea Region: a geopolitical dilemma?
}

\author{
Lada L. Roslycky
}

Published online: 3 February 2009

(C) The Author(s) 2009. This article is published with open access at Springerlink.com

\begin{abstract}
States are unique and individual entities. However, geographic proximity, a common history and fate may cause existential threats to have common causes and solutions. To understand how, and why, states experience transnational organized crime as a national security threat differently, it is necessary to learn about the states and the culture of organized crime in the geographic region in which they are embedded. The objective here is to present the Post-Soviet Political Criminal Nexus as a part of the identity of Newly Independent States in the Black Sea Region (Azerbaijan, Georgia, Moldova and Ukraine) which poses an international security threat and impedes democratic development.
\end{abstract}

Keywords Transnational organized crime - Post-Soviet political criminal nexus · Stage evolutionary approach · Newly Independant States in the Black Sea Region . Ukraine · Georgia · Moldova $\cdot$ Russia $\cdot$ Frozen conflicts $\cdot$ Black Sea $\cdot$ Separatism . Energy · Post-communist · Soviet · Corruption · Nomenklatura $\cdot$ SBU $\cdot$ Security BESC: "Community of Democratic Choice" Gazprom · Geopolitical

International security interests and concerns are coming to a focal point at the Black Sea, and it has been identified as the new front line to combating threats to international security, the core of which are caused by corruption and transnational crime (Asmus and Jackson 2004). Since antiquity, rather than uniting its littoral states the Black Sea Region (BSR) has served as a crossroad. To date, the region remains a political project. A successful realization of the Black Sea project would

\footnotetext{
L. L. Roslycky $(\bowtie)$

Department International Relations, Rijksuniversiteit Groningen, Groningen, The Netherlands e-mail: Lada_Roslycky@ksg.harvard.edu

e-mail: L.L.Roslyck@rug.nl

L. L. Roslycky

Harvard Black Sea Security Program/National Security Program, 79 John F. Kennedy Street, Cambridge, MA 02138, USA
} 
create a cooperative cultural, political and economic sea-triangle connecting nations from the West, Greater Middle East and Eurasia.

The region's diversity continues to complicate cooperation and peace (Japaridze, personal communication 23 May 2008). The dissolution of the Soviet Union and the enlargement processes of the North Atlantic Treaty Organization and the European Union have connected the West to the BSR in an unprecedented manner. Romania and Bulgaria's accession to the European Union have brought the Black Sea into the European Union's very own backyard, much to the discomfort of the Russian Federation.

The purpose of this article is to present the Post-Soviet political criminal nexus as a distinct layer of transnational organized crime in the Black Sea Region. In order to do so, its relation to the stage-evolutionary theory, frozen conflicts within the Newly Independent States in the Black Sea Region and international energy politics will be considered. In the final section, international regional mechanisms identifying organized crime and corruption as a security threat impeding the democratic proliferation within their territories are presented.

\section{The Soviet inheritance}

The Black Sea Region is no stranger to the political criminal nexus nor to organized, transnational crime and corruption (henceforth, transnational crime). Following the collapse of the Soviet Empire, the Newly Independent States in the BSR (Azerbaijan, Georgia, Moldova and Ukraine, henceforth NISBSR) inherited political and social networks. ${ }^{1}$ They emerged with a common "legacy of a lack of respect for the rule of law, absence of civil society, a large criminal underworld and shadow economy, endemic corruption and a demoralized law enforcement and legal apparatus. This legacy established the necessary preconditions for the development of a serious and sophisticated organized crime problem" (Shelly 1999).

The Post-Soviet space contains a group of states in transition and a particularly fertile environment for the development and use of the political criminal nexus (Godson 2004:1). Their "fluid and complex conditions" and "lack of functioning state structures" are conducive to the battle over the redistribution of power (Godson 2004:16). Lupsha identified this form of political-criminal cooperation as the "InFlux: Emergent" transnational organized group (Lupsha 1996:33). The 'In-Flux Emergent' transnational organized criminal groups materialize from the absence of civil society, insurgence or conflict and the groups and their members are usually linked to prior state institutions such as the intelligence, military or totalitarian bureaucratic and economic sectors (Lupsha 1996:33).

The transition from one system to another creates an "extremely favorable environment for former and current state officials to work with criminal opportunists" (Godson 2004:11). However, to understand the Post-Soviet political

\footnotetext{
${ }^{1}$ Although Armenia can be included in the Black Sea Region, I do not include it into the NISBSR regional security sub-complex. Its relations with the Russian Federation set it apart from the rest of the NISBSR. However, it is foreseeable that it may become a part of the NISBSR security sub-complex in the future.
} 
criminal nexus as an existential threat to Newly Independent (western leaning) states in the Black Sea Region, it is necessary to be familiar with the specifics of the society in which a large layer of their political criminal nexus merged.

The Post-Soviet political criminal nexus in the Newly Independent States in the Black Sea Region has its origins in the Soviet era (Godson 2004:11; Shelly 2004:200). The "unholy troika" of the mafia, nomenklatura and current and former members of the government, military and security services is not a phenomenon that suddenly appeared with the fall of the Iron Curtain (McCauley 2001:75). Rather, it is a result of a dynamic process captured by the stage-evolutionary theory of organized crime.

In the predatory stage, organized criminals aggressively move to gain territory and power against the state (Lupsha 1996:31). The oldest known organized criminals in Russia are the Vory-v-Zakone (thieves in law). Dating back to Russian Empirical times, the original nature of this organization was that of 'predator' against the state. The state was perceived as the enemy and any "Vor" (thief) who would act to the benefit of the state was punished by death.

The parasitic stage is where the organized criminals feed off the state, penetrating the establishment (Lupsha 1996:32; Naylor 1993:21). Progressing to the parasitic stage, anti-state Vory-v-Zakone transformed into an unofficial instrument used by the state against the political enemies of the Soviet regime. At this level, even though organized criminals fed off the formal structures, the Soviet regime still controlled the political-criminal relation.

In the symbiotic stage, the relationship between the upper world and organized criminals enters the level of symbiosis where the two sides feed off each other (Lupsha 1996: 32). It was after Stalin's death in 1953 that political-criminal relations transformed. This transformation was marked by the sponsoring of the black market in which apparatchiks offered protection from the law in exchange for bribes (Sokolov 2004:69). Their [Vory-v-Zakone] leaders or "shop managers" were paid an illicit 30 percent margin for acquiring scarce consumer goods and diverting raw materials and finished goods from production lines to the benefit of the Nomenklatura, or the educated elite, and criminals (FBI 2008).

Symbiotic political-criminal relations became inherent to the communist culture, which rewarded party members with status and access to informal structures and the shadow economy. This "reward system" legitimized the shadow economy and was, ironically, partially responsible for keeping the Soviet economy afloat. At this level of political-criminal relations, the political no longer merely used criminals for its purposes; it became dependent on them infesting the Soviet state and economy with corrupt and criminal elements (Schulte-Bockholt 2006:164).

Usually, the stage evolutionary theory is applied to political-criminal analysis within a single nation state: the fall of the Russo-Soviet Empire allows it to be extrapolated to the international level. The USSR was a highly centralized political amalgamation of states, nationalities and cultures. Among the remnants of the centralized Soviet machine are the "ties among members of successor governments that give the government in Moscow strong influence over most of the former Soviet Union" (Roeder 1997:243).

These ties help explain the existence of the Russian sphere of influence beyond its territory (Roeder 1997:229-230). Today part of the 'old network' has converted 
itself into an international security problem. The networks or "sviaszi" now transgress international borders, stretching across the former Soviet Union and forming the region's Post-Soviet "contemporary political-criminal nexus" (Shelly 2004:209).

Importantly, the focus here is on the upper crust of organized criminals," the political and financial power of organized criminals of the Soviet establishment" that "strongly influenced the economic and political structures that emerged in the Commonwealth of Independent States since 1991" (Schulte-Bockholt 2006:168). Soviet elite, nomenklatura and intelligence networks were also partially preserved by the fact that much of the formerly state-owned property has been appropriated by them (Shelly 2004:200). This, in light of claims that the influence of organized crime in Russia has waned when compared to that of rent-seeking oligarchs, large corporations, and the state security services (Sokolov 2004:68).

The Russian Federation continues to perceive Western democracy and presence (through NATO) in the Black Sea Region as a threat. In this context, it is possible to understand how Russia's "controlled criminalism" could serve as a weapon against the proliferation of democracy in the Newly Independent States in the Black Sea Region (Story 2000: 97). The United States recognizes these networks of influence and, "going back to the Kremlin, the existence of that knowledge helps one understand certain motivations, activities and tools the Kremlin will and can use to exercise their political and commercial ambitions" (Merkel D., personal communication 12 June 2008).

Romania, Bulgaria and the Baltic States have broken free from the former communist or Supreme Soviet grip and have successfully entered the Euro-Atlantic integration process. However, Moscow's influence on the strategic territories of its former empire should not be underestimated. Importantly, parts of the former Soviet nomenklatura have been linked to separatism and transnational crime in the BSR (Shelly 1999).

\section{Separatism, imperialism and transnational crime}

The ancient Greek name for the Black Sea, Pontos Axeninos, means 'dark or somber sea'(King 2004:xi). Nomen est omen; today, the naturally beautiful Black Sea Region hosts a number of frozen conflicts and breakaway territories which have transformed into what are quite commonly referred to as criminal black holes. Moscow may not have only backed separatism resulting in "frozen conflicts" and breakaway territories in Moldova (Trans-Dniester) and Georgia (Abkhazia and South Ossetia), it has been asserted that these separatist sentiments have actually been "orchestrated, and are being maintained, by Moscow's policies" (Socor 2004:127). In this respect, Moscow's involvement in Azerbaijan and Armenia (NagornoKarabakh) and growing separatism in Ukraine (Sevastopol, Crimea) should also be considered.

Policies aimed at separatism do not promote the region's stability, the development of poorer states nor the proliferation of democracy. Rather, separatism in the NISBSR has a symbiotic relationship with transnational organized crime and terrorism (CEPS 2005). Due to the relatively meager salaries that can be earned 
legally within these states, the cost benefit ratio for committing crime is conducive to its proliferation. Furthermore, the aforementioned breakaway territories, de facto states, exercise internal sovereignty without external legitimation. Therefore, "it stands to reason that their form of government will be considered illegitimate and their sources of revenue illegal" (Kemp 2004:46).

Inadvertently, the criminalization and corruption of the populations living inside of these territories impedes the rule of law and the state's de facto control over its territory and population. If the effects of transnational crime in the region were limited to the territories in question, it in itself would not form as great a threat to democracy and freedom as it does today. The matter is that the effects of human trafficking (the modern day slave trade), contraband product trade and illegal arms trade has an international butterfly effect on human, economic, territorial and financial security.

To understand the problem of transnational crime within the Newly Independent States in the Black Sea Region adequately, the way it promotes separatism and Russia's geopolitical interests must be taken into consideration.

The presence and activities of pro-Russian forces inside of these territories, including armed forces and political-economic companies such as Gazprom, facilitate the extension of Russia's power in the region. Of great importance is the fact that the international crime inherent to frozen conflicts and breakaway territories, also negatively affects the security within Russia's legitimate territory and, paradoxically, its interest in resolving transnational crime in the BSR. This ironic catch 22 for the Russian state is a common reality for actors who support ethnic conflict (Kemp 2004:45).

\section{Linking up to energy}

The war on terrorism, the war in Iraq and energy wars have created the need for the US and Europe to secure and diversify their energy sources away from Saudi Arabia and the Persian Gulf. The Black Sea Region is an ideal conduit by which nonOPEC, non-Gulf oil and natural gas can flow into European markets (Hitchner 2004:27). Moscow has reacted well to this change and has flexed its muscles towards its neighbors, close by and far away.

The increased dependency on Moscow's energy supplies has inadvertently tied its customers to more than a "questionably democratic" Russian State. Some of the actors involved with 'legitimate' government and big business may be directly involved in organized, transnational criminal activity thereby strengthening criminal networks, corruption and destabilizing internal, regional and international politics.

The nature of Gazprom's character is illustrated by its consideration to offer proRussian, and illegitimate, Transdniestria gas supplies separately from Moldova (European Weekly 2007). Not only has the Russian Security service been linked to the executive of Gazprom, the SBU (Ukraine's intelligence service) has linked Russia's State oil group, to an international organized crime group headed by Semyon Mogilevich. In 2003, the US Justice Department identified Mogilevich as the leader of a gang of more than 300 criminals, operating in more than 30 
countries, involved in "murder, extortion, trafficking in women for prostitution, smuggling, money laundering, and bank and securities fraud and, in numerous countries, the corruption of public officials" (ForUm 2005). A SBU spokesperson stated, "The probe is part of a broader investigation into suspected moneylaundering, smuggling and tax evasion stemming from the Turkmen gas trade. It will further aggravate Kyiv's strained relations with Russia and Gazprom, while highlighting the new Ukrainian government's struggle to overcome corrupt practices."(ForUm 2005).

\section{Regional governmental organizations}

What role do BSR governmental organizations play to combat transnational crime?

Experts have pointed to the need for BSR States to take on a common approach to deterring terrorism, drugs and weapons smuggling, as well as contraband, illegal migration and trafficking of human beings (Pop 2004:76). The region's multi-ethnic, multi-religions and political character, complicate a coherent regional approach to combating transnational organized crime. There is also no common approach to controlled deliveries in the region. Importantly, distinguishing between legitimate and illegitimate trade is extremely difficult in the region (Mednikarov and Kalinov, unpublished manuscript). Nonetheless, a number of regional governmental organizations have included the fight against international organized crime and corruption into their objectives.

In 1995, The Organization of Black Sea Economic Co-operation (BSEC) was one of the first Black Sea Regional organizations to identify transnational crime and terrorism as serious threats to the region's economic stability and security (BSEC 1995). BSEC has a special working group for organized crime. In 2002, the organization created the Agreement among the Governments of the BSEC Participating States on Cooperation in Combating Crime, in Particular in its Organised Forms. The agreement does not define "organized crime" or "terrorism" yet, unlike the UN Convention on the Prevention of Organized Crime that targets "serious crime" punishable by a maximum deprivation of liberty of at least 4 years, the BSEC agreement describes the specific crimes to be prevented, suppressed, detected, disclosed and investigated in cooperation.

In 2005, the Community of Democratic Choice (largely made up of former Soviet and Communist states) followed suit. Its Parties identified the need to "encourage the respect for democracy and human rights and to address the threats to the democratic development of society, which are-among others-corruption, organized crime, money laundering, terrorism in its different forms, the existence of remaining conflicts in Europe and illicit trafficking in drugs, arms and human beings (CDC 2005). It is still unclear which mechanisms will be implemented by the organization or how.

On 23 May 2006, the Presidents of the Republic of Azerbaijan, Georgia, the Republic of Moldova and Ukraine took part at the GUAM Summit in Kyiv (Ukraine). Presidents of Lithuania and Poland, Vice-President of Bulgaria, and highlevel representatives of Romania, Kazakhstan, representatives of the USA and of 
international organizations, such as the OSCE, BSEC and diplomatic missions participated. Special attention was paid to the challenges and threats of aggressive separatism and extremism, and transnational organized crime. "Unresolved conflicts and the illegal presence of foreign troops and armaments in GUAM States" were also recognized as main obstacles to full-scale democratic transformations and economic development in the region (GUAM 2006).

Other regional institutions include the Black Sea Naval Task Group (BLACKSEAFOR created to enhance peace and stability in the BSR), and the 2004 Border Defense Initiative (BDI), known also as the Black Sea Border Security Initiative launched in Bucharest. BLACKSEAFOR and Project Black Sea Harmony are projects initiated by the Turkish State in 1998 and 2004, respectively. Both aim at diminishing the prevalence of illicit activity on the Black Sea through international cooperation.

Whereas regional and international institutions are in place, and have even created certain basic mechanisms to counteract transnational crime, they have yet to be perfected and coordinated in an effective manner. Their effect must not be limited to nipping organized crime in the bud, it must make the penalization of the actors involved a reality.

\section{Conclusion}

International security problems related to transnational crime in the Newly Independent States in the Black Sea Region have a specific character. The stage evolutionary approach to organized crime shows how the formally centralized political criminal relations of the Soviet Union have transformed into a modern day, international security threat.

Recognizing the Post-Soviet identity within the NISBSR political criminal nexus facilitates the comprehension of both internal political strife and geopolitics in the region. The remnants of communist and Soviet networks, identified here as the PostSoviet political criminal nexus, may be used to advance anti-democratic motives.

Frozen conflicts and breakaway territories simultaneously violate the territorial integrity and democratic development of sovereign states. They not only cause the spread of organized criminal activity they depend on it. Geopolitical energy wars being fought for territorial loyalty appear to carry a severe element of corruption and crime. People and states alike are the victims.

The prevalence of transnational crime in the Newly Independent States in the Black Sea Region's business and political affairs is related to a Soviet inheritance, the lack of the rule of law and punitive mechanisms in the international community. Intergovernmental initiatives notwithstanding, there is no single, effective effort to combating transnational organized crime in the Black Sea Region. As a result, the cost/benefit ratio for committing crime on a subject or even state level is unsatisfactory and therefore conducive to it.

One may argue that organized crime is as old as human kind and what time does not resolve is not a problem. It is not sufficient to identify and analyze the key political-criminal activities in the BSR. Individual actors as well as states should be held responsible for the transnational organized crimes they commit. To realize the 
Black Sea Region project and create a stable, prosperous and cooperative region, the rule of law and democratic freedom must be established. They are requisite for effective strategies and policies that will secure the Black Sea Region, its population and the international community at large.

Open Access This article is distributed under the terms of the Creative Commons Attribution Noncommercial License which permits any noncommercial use, distribution, and reproduction in any medium, provided the original author(s) and source are credited.

\section{References}

Asmus RD, Jackson BP (2004) The Black Sea and the frontiers of freedom. In: A new Euro-Atlantic strategy for the Black Sea Region, The George Marshall Fund of the United States, Washington

BSEC (1995) Statement of the High Level meeting of the BSEC participating States Bucharest, 30 June 1995, available at International Center for Black Sea Studies: http://icbss.org/index.php? option $=$ com_docman\&task $=$ doc_download\&gid $=437$

CDC (2005) Community of democratic choice declaration of the countries of the democratic community, Kyiv December available at: http://ukraine-eu.mfa.gov.ua/eu/en/news/detail/1377.htm?lightWords= laundering

Center of European Policy Studies, The EU and Black Sea Regional cooperation: some challenges for BSEC 2005 available at: http://www.ceps.be/wp.php?article_id=420

European Weekly (2007) "New Europe" Gazprom may Split Moldova, Transdniester Contract March, Issue 719 available at: http://www.neurope.eu/view news.php?id=70821

Federal Bureau of Investigation (2008) The history of Eurasian Organized Crime available at: http://www. fbi.gov/hq/cid/orgcrime/eocindex.htm

ForUm (2005) Security services of Ukraine accuses Gazprom of link to international organised crime group, 28 July, available at http://en.for-ua.com/news/2005/07/28/153021.html

Godson R (2004) The political-criminal nexus and global security. In: Godson R (ed) Menace to society political-criminal collaboration around the world. Transaction, London

GUAM Summit Communiqué (2006) available at http://www.mfa.gov.az/az/guam/2006_CMFA_0522_ communique $\% 20$ eng.pdf

Hitchner RB (2004) The sea friendly to strangers: history and the making of a Euro-Atlantic strategy for the Black Sea. In: Asmus RD (ed) A new Euro-Atlantic strategy for the Black Sea Region, The German Marshall Fund of the United States

Kemp WA (2004) The business of ethnic conflict. Secur Dialogue 35(1):43-59. doi:10.1177/ 0967010604042535

King C (2004) The Black Sea: a history. Oxford University Press, New York

Lupsha PA (1996) Transnational organized crime versus the nation-state. Transnatl Organ Crime 2(1):2148

McCauley M (2001) Bandits gangsters and the Mafia: Russia, the Baltic States and the Mafia. Pearson, London

Naylor RT (1993) The insurgent economy: black market operations of guerrilla organizations. Crime Law Soc Change 20:13-51. doi:10.1007/BF01308447

Pop A (2004) Regionalism, sub-regionalism and security in the Black Sea Region: research summary". In: Euro-Atlantic Studies, No. 7, 2004, University of Bucharest, Centre for Euro-Atlantic Studies

Roeder (1997) From hierarchy to hegemony: the post-Soviet security complex. In: Lake DA, Morgan PM (eds) Regional orders: building security in a New World University of California Institute on global conflict and cooperation

Schulte-Bockholt A (2006) The politics of organized crime and the organized crime of politics: a study in criminal power. Lexington Books, Oxford

Shelly L (1999) Organized crime in the former Soviet union: the distinctiveness of Georgia available from Transnational Crime and corruption Center Webmaster http://www.traccc.cdn.ge/publications/index subject.html\#crime 
Shelly L (2004) Russia and Ukraine: transition or tragedy? In: Godson R (ed) Menace to society politicalcriminal collaboration around the world. Transaction, London

Socor V (2004) Frozen conflicts: a challenge to Euro-Atlantic interests. In: Asmus RU, Dimitrov K, Forbrig J (eds) A new Euro-Atlantic strategy in the Black Sea region. German Marshall Fund of the United States, Washington, pp 127-137

Sokolov V (2004) From guns to briefcases: the Evolution of Russian organized crime. World Policy J XXI (1):69 (spring)

Story C (2000) Criminalism - the Russian 'mafia' is not free-standing. International Currency Review 25 (3), 1999-2000 London Currency Review: London, p 97 